\title{
Application of IT-Integrated Project-Based Learning in the Teaching Reform of Undergraduate Education
}

\author{
https://doi.org/10.3991/ijet.v16i05.21085 \\ Huirong Chen, Jianzhong Yang $(\varpi)$ \\ Beibu Gulf University, Qinzhou, China \\ jianzhongzhong@126.com
}

\begin{abstract}
To innovate the traditional teaching method of normal colleges and enhance their teaching effect, this paper employed the Action Research method to develop a novel and demand-oriented teaching mode in the context of information age, the Information Technology (IT)-integrated Project-based Learning $(\mathrm{PjBL})$ teaching mode, which was then applied to the teaching of the course Modern Education Technology to explore its effect in teaching reform. With the IT-integrated PjBL teaching mode, this study attempted to conduct structural reform on the said course, solve problems in course teaching, and reflect upon the defects of the proposed IT-integrated PjBL teaching mode. The main research conclusions are: (1) The IT-integrated PjBL teaching mode requires teachers to fully understand the real-world demands and form a demand-oriented teaching idea; (2) The teaching content framework should be sorted and integrated based on the project demands; (3) Students' initiative and personal specialties should be fully motivated during team building; (4) A regular reporting system should be established to supervise the teaching process and it should be implemented strictly; (5) Learning contests can inspect students' learning effect while boosting their sense of accomplishment, which is exactly the impetus for the continuous learning of students. The research findings of this paper provided a reference for the reform of teaching idea and teaching practice of undergraduate education in the context of information age.
\end{abstract}

Keywords-IT-integrated Project-based Learning (PjBL), teaching mode, undergraduate education, action research

\section{Introduction}

The term "Project-Based Learning (PjBL)" is originally derived from the book Experience and Education [1] written by John Dewey, and then the idea had been further developed by his student W.H. Kilpatrick [2]. Dewey advocated to take purposeful activities as the key link of teaching process and the basis of effective learning, and the teaching method should be designed based on the learning interests and practical demands, and such teaching method is generally regarded as the predecessor of PjBL. However, the concept of $\mathrm{PjBL}$ is officially and widely recognized as the definition given by Thomas [3] in 2005, he believes that PjBL is an exploratory learning mode developed around projects, projects are complex tasks, in order to complete the goals 
of the projects, learners must launch surveys, participate in design, solve problems and make decisions. PjBL gives learners greater work freedom, and in the end, the projects are terminated by giving presentations or delivering actual products [4].

The Buck Institute of Education in the United States defines PjBL as a set of systematic teaching methods. It is a process of exploring complex and real problems, and also a process of carefully devising project works, and planning and implementing the project tasks; and during such process, students could master the knowledge and skills they need [5]. From the perspective of education theory, PjBL is a constructivist theory which improves the learning effects of students and trains their skills by involving them in projects [6].Currently, some engineering associations and appraisal committees in the United States, the United Kingdom, Australia, Malaysia and other countries have changed the identification criteria of learners from "what has been taught" to "what has been learned" [7]; and the Curriculum Development Committee (CDC) of Hong Kong is also actively promoting the PjBL teaching mode [8].

In recent years, scholars have applied PjBL to the training of oral English skills [9], the cultivation of the research ability of financial graduate [10], as well as the teaching of physics [11-12], mathematics [13], and core literacy [14-15], etc.; their research results proved that $\mathrm{PjBL}$ can significantly improve the teaching effect of elementary education [16-18], secondary education [19-21] and higher education [22-24]; and their research mostly started from specific disciplines and selected or built projects according to scientific standards. Nowadays, information technology is booming, if we can combine information technology with PjBL, then the teaching resources could be re-integrated to serve students' autonomous learning, promote learning with project-based tasks, and enable students to learn and practice according to their actual needs.

Modern Education Technology is a compulsory course for normal college students, it can reflect the characteristics of normal education. According to the nature, teaching objective, and teaching environment of this course, this paper employed actual projects in the real world to construct the IT-integrated PjBL teaching mode in the context of information age, and adopted the Action Research method to factually record classroom teaching and provide a reference for the teaching reform.

\section{Problem Proposal}

\subsection{Problems in traditional teaching method}

The traditional teaching method of the Modern Education Technology course divides the teaching content into several chapters according the categories of the knowledge points; such method is convenient for classroom teaching but it cuts the connections between knowledge points. In terms of teaching-learning interaction, the traditional classroom teaching is like a screenplay, teachers are at the center of the stage while students participate passively like audience and lack initiative. In terms of teaching evaluation, in a long time, it's been advocated that the process evaluation and result evaluation should be united, and the single evaluation and comprehensive 
evaluation should be united as well; however, the actual operations of process evaluation and comprehensive evaluation can hardly be implemented in traditional course teaching.

\subsection{Introduction of the PjBL teaching mode}

In terms of course nature, Modern Education Technology course is an application subject that integrates theory, practice and innovation, and it emphasizes practice and innovation. In terms of audience, Modern Education Technology course is for students of normal colleges and universities, who have had certain self-learning and selfsupervision abilities. In terms of teaching environment, the advanced hardware devices such as mobile phones, computers, tablets and the wireless network have provided massive learning resources for modern teaching, therefore, in the teaching process, we should make full use of these resources to trigger students' learning interests and motivate their creativity, also, we could use network space to construct teaching scenarios based on actual needs, and guide students to learn the modern education technologies by using them in practice.

The course nature and teaching content of Modern Education Technology require that the teaching of this course should focus on practice and innovation, and the audience group and teaching environment of this course provide conditions for the implementation of $\mathrm{PjBL}$, and the $\mathrm{PjBL}$ teaching mode has pointed out a way for realizing the teaching goal of the Modern Education Technology course.

\subsection{Problems to be solved}

1. Construct demand-oriented teaching content for the Modern Education Technology course: The PjBL teaching mode takes the demands of actual projects as the starting point, it re-organizes the teaching content, helps students understand the solving process of actual problems and re-constructs their knowledge framework. Based on traditional $\mathrm{PjBL}$, the $\mathrm{PjBL}$ teaching mode integrating information technology (IT-integrated PjBL) offers students with massive online learning resources and greatly alters the traditional teaching method of the Modern Education Technology course, such as using multimedia courseware to display the teaching content, and giving demonstrations in the classroom.

2. Create a student-centered teaching-learning interaction environment: With the help of the IT-integrated $\mathrm{PjBL}$ teaching mode, teachers can make video clips of the operating steps and skills, and offer other online video clips for students, so that they can use their pockets of time to learn at any time anywhere; meanwhile, the IT-integrated $\mathrm{PjBL}$ teaching mode has changed teachers' classroom demonstration to remote control and network transmission, realizing hi-tech teaching methods; moreover, by integrating learning platforms and online communication tools with teaching, we can better create a student-centered teaching-learning interaction environment.

3. Realize informationized teaching management: The traditional teaching organizational form which takes class as per unit is no longer applicable. The IT- 
integrated $\mathrm{PjBL}$ teaching mode is a combination of teaching forms integrating personalized learning, group discussion, instant teacher-student communication, seminars, and face-to-face lecturing, etc. Under the IT-integrated PjBL teaching mode, students are no longer passive knowledge receivers, but active knowledge seekers. Students' prior experience and knowledge not only can promote their own learning, but also can drive other students to learn together.

Under the IT-integrated PjBL teaching mode, first, students can use study notes, mind maps and other informationizedi learning methods to study the online learning materials or the learning materials provided by the teachers by themselves; then, they can report their learning situation, discuss with others, ask questions, and conduct group learning on the learning platforms or network communication tools; after that, they can combine with classroom teaching, and collaborate with the lab teams to work on actual projects to conduct co-learning, and thereby realizing informationized teaching management.

4. Realize informationized teaching evaluation: With the help of information technology, the process evaluation and comprehensive evaluation have become realizable. This paper took a cloud-class mobile learning platform as an example to collect the process data of the teaching and learning processes and the learning trajectories, which provided data support for teaching process evaluation and comprehensive teaching evaluation.

\section{Construction of the IT-Integrated PjBL Teaching Mode}

The IT boom has promoted the informationized progress of the education field, which directly drives the education mode to reform and upgrade. As mentioned in previous chapter, Modern Education Technology course is an application subject that integrates theory, practice and innovation, it takes actual demands as the orientation, its target audience is students of normal colleges, and its teaching environment is supported by various information technologies; therefore, combining with modern learning theories, this paper constructed the IT-integrated PjBL teaching mode as shown in Figure 1. 
Paper-Application of IT-Integrated Project-Based Learning in the Teaching Reform of Undergraduate..

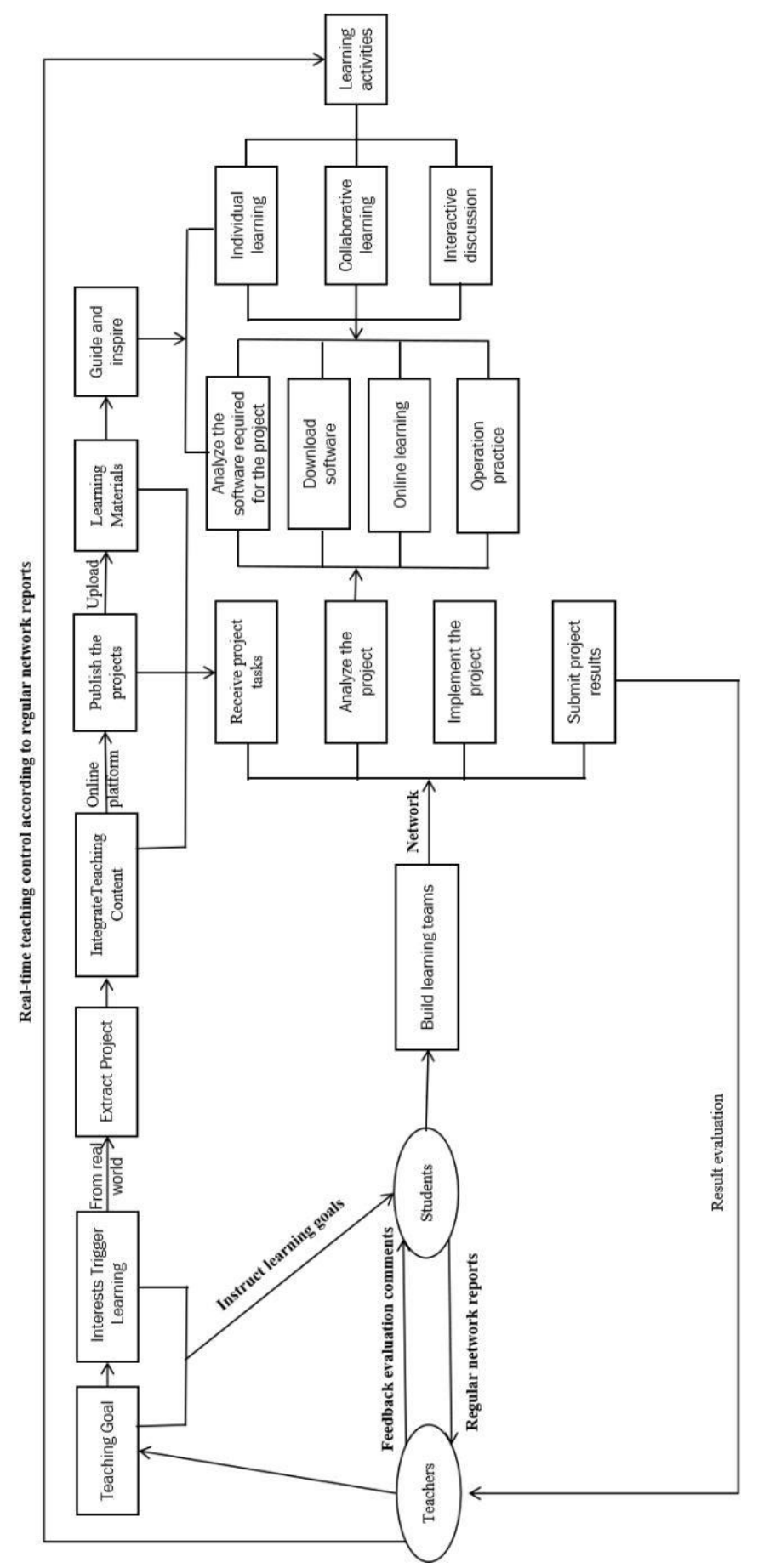

Fig. 1. A diagram of the IT-integrated PjBL teaching mode 


\section{$4 \quad$ Action Planning}

\subsection{Personnel organization}

Participants in this teaching reform program were 48 sophomores from Beibu Gulf University, Guangxi Province, China. Before taking the Modern Education Technology course, they had already learnt the Pedagogy course, the Psychology course, the College Computer course and other prior courses, and they had certain Pedagogy knowledge and computer operation skills.

All participants grouped into small teams of 4-6 people at will. Each team had a captain who was responsible for coordinating team members, setting network communication tools and controlling the project quality; team members divided their works by themselves, and each member was responsible for controlling the quality of a project link such as teaching design, PPT design, content explanation, shooting, dubbing, and editing, etc. Team members exerted their respective strong suit and cooperated in the learning project.

\subsection{Project settings}

1. Real project

Table 1. Sub-projects of the micro-class series Practical Information Technologies for Geography Teaching

\begin{tabular}{|c|c|c|}
\hline \multicolumn{3}{|c|}{ Micro-class series: Practical Information Technologies for Geography Teaching } \\
\hline Number & Sub-project & Software required \\
\hline $1 \sim 6$ & $\begin{array}{l}\text { Collect and process texts, maps, images, audios, } \\
\text { geographic videos, geographic animation and other } \\
\text { materials }\end{array}$ & PPT courseware \\
\hline $7 \sim 8$ & $\begin{array}{l}\text { Geography courseware integration skills-_ } \\
\text { PowerPoint, Authware }\end{array}$ & PowerPoint, Authware \\
\hline 9 & Interactive-type courseware making skills & Seewo Whiteboard \\
\hline 10 & $\begin{array}{l}\text { Mobile learning-type courseware (H5 courseware) } \\
\text { making skills }\end{array}$ & 91Suke \\
\hline $11 \sim 12$ & Micro-class and online course making & $\begin{array}{l}\text { Wcapture, Camtasia Studio and other } \\
\text { screen recording software }\end{array}$ \\
\hline $13 \sim 15$ & $\begin{array}{l}\text { Informationized Class management platforms- } \\
\text { Mosoink cloud class, Teachermate, Rain Classroom }\end{array}$ & $\begin{array}{l}\text { Mosoink cloud class, Teachermate, Rain } \\
\text { Classroom }\end{array}$ \\
\hline $16 \sim 18$ & $\begin{array}{l}\text { Geography APP_— Solar Walk Lite, Stellarium, } \\
\text { Terra Time }\end{array}$ & Solar Walk Lite, Stellarium, Terra Time \\
\hline $19 \sim 20$ & $\begin{array}{l}\text { Informationized teaching environment introduc- } \\
\text { tion_-Geography virtual simulation experiment, } \\
\text { digital geography classroom }\end{array}$ & PPT courseware \\
\hline
\end{tabular}

In this study, the real project micro-class series Practical Information Technologies for Geography Teaching was launched and divided into several sub-projects for students to choose (see Table 1). It should be noted that although the project had been divided into several sub-projects, the implementation process of the sub-projects was 
basically the same, common links included: teaching design, PPT design, content explanation, shooting, dubbing, and editing, etc. Therefore, even if the participants choose different sub-projects, the knowledge and skills they acquired from the project implementation process were able to achieve the teaching goal of the course.

2. Task requirements: The requirements of the tasks included: choose a sub-project, design the PPT, make a 4-8 minutes micro-class video and upload the PPT and the video to the cloud class. The flow of micro-class video making included: download and install software, learn the software, write speech notes, design PPT, record sample video, edit video, and save as MP4 file. When recording the sample video, participants may take multiple attempts, if there's a slip of tongue, just pause the recording and start again from the slip sentence, editor can cut the slip sentence later, so the recording doesn't have to start from the beginning again, participants can choose the screen recording software by themselves.

3. Scoring criteria

Table 2. Scoring criteria

\begin{tabular}{|c|c|c|c|c|}
\hline $\begin{array}{l}\text { Learn- } \\
\text { ing } \\
\text { result }\end{array}$ & Content & Score & Scoring criterion & Judge \\
\hline $\begin{array}{l}\text { Learn- } \\
\text { ing } \\
\text { process }\end{array}$ & \begin{tabular}{|l|} 
Material reading, video \\
watching, student-student \\
interaction, teacher- \\
student interaction and \\
other learning trajectories \\
in PjBL process
\end{tabular} & 20 & $\begin{array}{l}\text { Material learning/20\%, attendance } / 5 \% \text {, } \\
\text { exams } / 20 \%, \text { Easy-webcast/discussion/20\%, } \\
\text { brainstorm/5\%, poll survey/5\%, assign- } \\
\text { ment/team task/20\%, bonus point for class- } \\
\text { room performance given by teachers } / 10 \%\end{array}$ & $\begin{array}{l}\text { Data of learning } \\
\text { trajectories } \\
\text { exported from } \\
\text { the cloud-class } \\
\text { platform }\end{array}$ \\
\hline PPT & $\begin{array}{l}\text { Courseware should con- } \\
\text { tain front cover, back } \\
\text { cover, catalog page, } \\
\text { names of designers, } \\
\text { design date and other } \\
\text { elements. }\end{array}$ & 30 & $\begin{array}{l}\text { Examples are reasonable and materials are } \\
\text { accurate and authentic/20\%; the design of } \\
\text { images, animations, sounds, and texts is } \\
\text { reasonable/20\%; images are clear, layout is } \\
\text { reasonable, animations are smooth } / 20 \% \text {; } \\
\text { navigation structure is clear and reasonable, } \\
\text { with good classroom interaction design } / 30 \% \text {; } \\
\text { good adaptability, can operate normally on } \\
\text { other computers or terminals } \\
110 \%\end{array}$ & $\begin{array}{l}\text { Teacher/60\% } \\
\text { all classmates } \\
140 \%\end{array}$ \\
\hline $\begin{array}{l}\text { Micro- } \\
\text { class }\end{array}$ & $\begin{array}{l}\text { Use screen recording, } \\
\text { shooting or other means to } \\
\text { make a 5-8 minutes video, } \\
\text { the video should have } \\
\text { correct content, clear } \\
\text { logic, complete structure, } \\
\text { and the key content } \\
\text { should be highlighted. }\end{array}$ & 50 & $\begin{array}{l}\text { Topic is concise and to the point } / 10 \% \text {, } \\
\text { reasonable design } / 10 \% \text {, scientific and correct } \\
\text { content } / 20 \% \text {, clear logic } / 20 \% \text {, complete } \\
\text { structure } / 10 \% \text {, } \\
\text { standard technique application } / 20 \% \text {, stand- } \\
\text { ard language expression } / 10 \%\end{array}$ & $\begin{array}{l}\text { Teacher } 60 \% \\
\text { all classmates } \\
/ 40 \%\end{array}$ \\
\hline
\end{tabular}

Under the IT-integrated PjBL teaching mode, the evaluation of the teaching effect of the Modern Education Technology course focused on combining learning process evaluation with learning result evaluation, and combining the self-evaluation of teachers and students with their mutual evaluation; the evaluation was conducted from multiple aspects. With the help of the cloud class mobile learning platform, 
the process data of the teaching-learning processes and the learning trajectories were collected, which provided a data support for the process evaluation and comprehensive evaluation.

The full mark of the course was 100 points, including 20 points for learning process, 30 points for PPT design and making, and 50 points for micro-class making. The learning process data was exported from the cloud class platform. The PPT and micro-class were scored by teachers and all classmates, the score given by teachers accounted for $60 \%$ and the score given by other students accounted for $40 \%$ (Table 2).

4. Learning supervision: Learning is an autonomous or passive-autonomous behavior of the human brain under the combined action of the internal and external driving forces. The learning behavior requires long time lasting, and it requires the joint effort of both the internal and external driving forces. The internal driving force mainly refers to the voluntary learning behavior of the learner since he/she has realized the importance of knowledge, and the external driving force mainly refers to the learning behavior of the learner driven by external factors. Generally speaking, internal driving force produces autonomous learning behavior, and external driving force produces passive-autonomous learning behavior. However, internal driving force can hardly last for a long time, and external driving force must work together with it to keep the learning behavior going on.

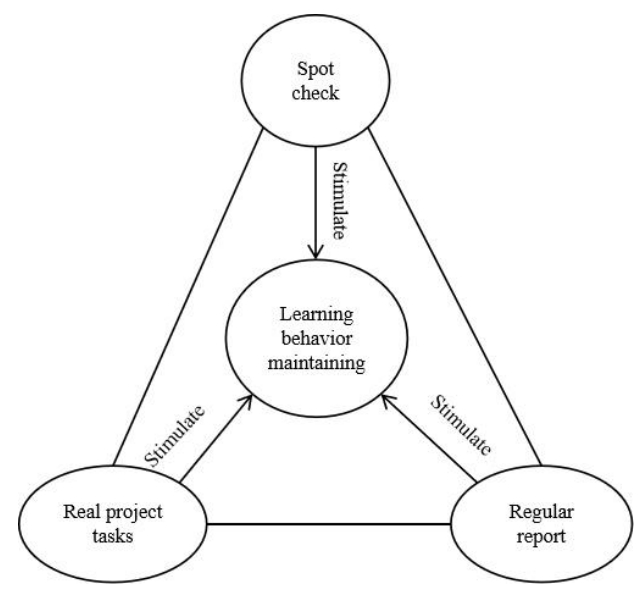

Fig. 2. Model of learning supervision

Under a network environment, the PjBL teaching mode applied to the Modern Education Technology course adopted measures from both aspects of the internal and external driving forces, and the two had joined their efforts to keep the learning behaviour going on (Figure 2). On the one hand, with actual demands as the orientation, contests were held to trigger students' internal driving force; on the other hand, real projects were introduced, and two kinds of external driving forces (regular reports and random tests) were adopted to keep the learning behaviour going on. Regular reports included the regular reports of team members and the regular reports of the team cap- 
tains to the teacher. Starting from the assignment of project tasks, students were instructed to make project plans and determine the task completion time. During the project period, at $3 \mathrm{pm}$ of every Sunday, the team captains organized the team members to report their learning progress and the difficulties they encountered, the team captains made a record of these situations and reported to the teacher at $3 \mathrm{pm}$ of every Monday. Also, in the process of $\mathrm{PjBL}$, teachers spot checked students' learning progress from time to time.

5. Learning environment: For the IT-integrated PjBL teaching mode, the hardware equipment included computers, smart phones and tablets, and the software included cloud class APP, video editing software, audio editing software, screen recording software, office software, instant chat software and professional software. Using cloud class, network communication tools and other platforms, a virtual learning community was built to publish learning materials, share documents, conduct collaborative file editing, exchange with others, and have discussions. In China, MOOC, Tencent Classroom, Bilibili and other learning websites have massive learning resources, and students can use them to learn independently.

\subsection{Time arrangement}

The course hours of Modern Education Technology were 48 hours, 4 hours each week, and the course was completed in 12 weeks. After the IT-integrated PjBL teaching mode had been adopted, the conventional classroom teaching could no longer meet the teaching requirements. Therefore, the regular classroom course hours were used for theoretical explanations, and face-to-face exchange and instruction. The first week was the introduction stage, the main content included an introduction of the course, the explanation of learning goals, learning interest intriguing, and a few preparatory works for cloud class, network communication tools and team construction, etc. On the second week, the teacher published and analysed the projects, and students made selections on the projects. From the third week to the sixth week, students completed the learning of knowledge and skills required for the projects, implemented the projects, uploaded the mid-term results to the cloud class, and teachers and students discussed the measures to improve the projects. From the seventh week to the eleventh week, the final results were submitted, the project teams reported their works, and the works were scored. On the twelfth week, students submitted their study summary report and completed the evaluation of their daily performance.

\section{$5 \quad$ Action Implementation}

In the case study, a real project micro-class series Practical Information Technologies for Geography Teaching was launched to implement the proposed IT-integrated $\mathrm{PjBL}$ teaching mode in teaching practice. The specific implementation process can be divided into four steps: 


\subsection{Pre-class preparation}

Pre-class preparation included: create the course on the cloud class platform; display the teaching goals, learning requirements and assessment standards of the course; trigger interests and form learning teams with 4-6 students in each team. The interest intriguing adopted two methods; one was introducing the importance of multimediaassisted teaching in teaching practice combining with the specific course subject; the other was to hold contests to stimulate students' sense of accomplishment.

\subsection{Propose projects and integrate learning resources}

The real project micro-class series Practical Information Technologies for Geography Teaching was proposed and the integrated teaching content was introduced in the cloud class. Students were instructed to analyse the project form and figure out the required software and basic knowledge, then they used the open website to learn independently.

The project was divided into several sub-projects and shared through the Tencent documents. Students chose the sub-projects at their will. At the same time, learning materials were uploaded to the cloud class or network communication tools, and a few learning websites such as MOOC, Bilibili and Youku video were recommended to students.

\subsection{Implement project and submit results}

Students completed the project independently, including teaching design, PPT design and making, content explanation, recording, dubbing, editing, etc., and their project results were submitted for teachers to evaluate and make comments via the Tencent video conference. Then, students modified their projects again until the results met the actual demands. During this period, students regularly reported their learning progress and the difficulties they had encountered through video conference, in other time period, they used the instant communication tools to exchange with others.

\subsection{Summary and exchange}

After the project was completed, students exchanged with each other about their learning, they summarized and shared the knowledge and skills they learnt and the thoughts and feelings they hadin the projects. The main forms included group report and personal reflection. The learning teams reported their gains, difficulties and solutions they had during the course learning, and the students submitted their personal course learning reports. 


\section{Teaching Effect and Reflections}

Under the IT-integrated PiBL teaching mode, teachers can make full use of the advantages of the information technology, with the help of various online resources, they can provide students with rich and interesting learning materials, inspire them, expand their thinking dimensions, and encourage them to ask more questions. The proposed teaching mode can give full play to the information technology in promoting the teaching and learning of each discipline, and it made students to learn actively with their own questions; under this teaching mode, students took the dominant position in learning, and they can give feedback and evaluation, communicate and exchange with others, expand and diverge their thinking, and carry out practice and innovation.

The teaching practice program launched in 2018-2019 had lasted for nearly a year, during this period, the IT-integrated PjBL teaching mode had achieved good teaching effect. In 2019, the teaching practice program had won the first prize of the provincial normal student informationized teaching skills competition for the first time, and it had won all the first prizes in the teaching application-type contests of undergraduate institutions. In this process, I had a few thoughts:

1. The IT-integrated PjBL teaching mode requires the teachers to fully understand the real-world demands and form a demand-oriented teaching idea

2. The teaching content framework should be sorted and integrated based on the project demands

3. Students' initiative and personal specialties should be fully motivated during team building

4. A regular reporting system should be established to supervise the teaching process and it should be implemented strictly

5. Learning contests can inspect students' learning effect while boosting their sense of accomplishment, which is exactly the impetus for the continuous learning of students.

\section{$7 \quad$ Acknowledgement}

Key Educational Reform Projects of Qinzhou University key educational Reform projects of Qinzhou University are "Application Research of Flipped Classroom Based on Project Teaching" (17XJGZ18) and "Teaching Reform and Practice of Geographic Information System Principles Based on Project Teaching" (17XJGZ21).

\section{References}

[1] Dewey, J. (1986). Experience and education. In the Educational Forum, 50(3): 241-252. https://doi.org/10.1080/00131728609335764

[2] Rilpatrick, W.H. (1925). Foundations of method: Informal talks on teaching New York: Barber Press. 
[3] John, W.T., Thomas, W. (2000). A review of research on project-based learning. TA Foundation, California. http://www.autodesk.com/foundation,2005.7.18 .

[4] Jones, B.F., Rasmussen, C.M., Moffitt, M.C. (1997). Real-life problem solving: A collaborative approach to interdisciplinary learning. American Psychological Association. https://doi.org/10.1037/10266-000

[5] Buck Institute for Education. (2008). Project based learning handbook a guide to standards-focused project-based learning for middle and high school teachers 2nd Edition. Beijing: Education Science Press

[6] Mettas, A.C., Constantinou, C.C. (2008). The technology fair: a project-based learning approach for enhancing problem solving skills and interest in design and technology education. International Journal of Technology and Design Education, 18(1): 79-100. https ://doi.org/10.1007/s10798-006-9011-3

[7] Mills, J.E., Treagust, D.F. (2003). Engineering education-Is problem-based or projectbased learning the answer. Australasian journal of engineering education, 3(2): 2-16.

[8] Lam, S.F., Cheng, R.W.Y., Choy, H.C. (2010). School support and teacher motivation to implement project-based learning. Learning and instruction, 20(6): 487-497. https://doi. org/10.1016/j.learninstruc.2009.07.003

[9] Sayuti, H.A.M., Ann, T.G., Saimi, W.M.S.A., Bakar, M.A., Bakar, A., Dawawi, S.N.A., Mohamad, M. (2020). Using Gold Standard Project Based Learning for Intermediate Year Three Pupils to Enhance English Speaking Skill: A Conceptual Paper. Creative Education, 11(10): 1873-1889. https://doi.org/10.4236/ce.2020.1110137.

[10] Parrado-Martínez, P., Sánchez-Andújar, S. (2020). Development of competences in postgraduate studies of finance: A project-based learning (PBL) case study. International Review of Economics Education, 35: 100192. https://doi.org/10.1016/j.iree.2020.100192 .

[11] Wang, N.D. (2020). Project-based Learning Analysis based on original physical problems -- Taking "Electric fan Fire" inquiry project as an example. China Modern Educational Equipment, 2020(18): 47-48, 57. https://doi.org/10.13492/j.cnki.cmee.2020.18.016

[12] Peng, Y. (2020). Research on junior Middle School Physics Teaching based on projectbased learning method -- Taking "Making adjustable Luminance Flashlight" project as an example. Journal of Physics Teaching, 38(09): 64-66. https://doi.org/10.1080/00220671.20 $\underline{14.979911}$

[13] Holmes, V.L., Hwang, Y. (2016). Exploring the effects of project-based learning in secondary mathematics education. The Journal of Educational Research, 109(5): 449-463.

[14] Hu, H.X. (2017). Project-based Learning: Class Activities Developing Students' Core Qualities. Journal of Lanzhou University (Social Sciences), 45(6): 165-172.

[15] Tian, W.Q., Liu, S.H. (2020). Based on the discipline core literacy Information technology project-based instructional design--Take the program Selection Structure project as an example. China Information Technology Education, 2020(18): 58-59.

[16] Liang, W.P. (2020). A Preliminary Study on effective Evaluation of Project-based Learning in integral Teaching of Chinese unit in primary Schools. Kaoshi Zhoukan, 2020(83): 17-18.

[17] Huang, P.H. (2020). Development and Implementation of Multiple Reading Activities in Primary School under project-based learning -- Take class Reading Challenge Competition as an example. Xinkecheng Daoxue, 2020(25): 42-43.

[18] Gao, M. (2020). Project Learning and Inquiry of Primary School Chinese -- Taking "Hometown custom" teaching as an example. Information Technology Education in Primary and Secondary Schools, 2020(09): 46-49.

[19] Han, S., Capraro, R., Capraro, M.M. (2015). How science, technology, engineering, and mathematics (STEM) project-based learning (PBL) affects high, middle, and low achievers 
differently: The impact of student factors on achievement. International Journal of Science and Mathematics Education, 13(5): 1089-1113. https://doi.org/10.1007/s10763-014-9526-0

[20] Zhu, Q.Y. (2020). Project learning design and implementation of Junior Middle school Chinese News unit. Chinese Teaching \& Studies, 2020(9): 20-21.

[21] Panis, I.C., Setyosari, P., Kuswandi, D., Yuliati, L. (2020). Design gamification models in higher education: A study in Indonesia. International Journal of Emerging Technologies in Learning, 15(12): 244-255. https://doi.org/10.3991/ijet.v15i12.13965

[22] Zabolotniaia, M., Cheng, Z., Dorozhkin, E.M., Lyzhin, A.I. (2020). Use of the LMS Moodle for an effective implementation of an innovative policy in higher educational institutions, International Journal of Emerging Technologies in Learning, 15(13): 172-189. https ://doi.org/10.3991/ijet.v15i13.14945

[23] Shu, Y.N. (2017). Construction of teaching Process Quality management System based on Project-based Learning -- A case study of School of Mechanical and Power Engineering, Shanghai Jiao Tong University. Journal of Higher Education, 2017(19): 114-117.

[24] Chu, S.K.W., Zhang, Y., Chen, K., Chan, C.K., Lee, C.W.Y., Zou, E., Lau, W. (2017). The effectiveness of wikis for project-based learning in different disciplines in higher education. The internet and higher education, 33: 49-60. https://doi.org/10.1016/j.iheduc. $\underline{2017.01 .005}$.

\section{Authors}

Huirong Chen received the B.S. and M. Eng. degrees from Yunnan Normal University in 2011 and 2014. Now, she is a lecturer in the School of Resources and Environment at Beibu Gulf University, Guangxi, China. She is engaged in Geography curriculum design and teaching method research, information teaching, ecological economy (email: rongerdan@163.com).

Jianzhong Yang received the B.S. and M. Eng. degrees from Jiangxi Normal University and Guangxi Normal University in 2008 and 2011, respectively, and is presently an associate professor in School of Electric and Information Engineering, Beibu Gulf university. His research interests include image processing, pattern recognition and time series processing.

Article submitted 2021-01-13. Resubmitted 2021-02-15. Final acceptance 2021-02-16. Final version published as submitted by the authors. 